\title{
Transcriptional activity of oestrogen receptors in the course of embryo development
}

\author{
Sara Della Torre1,2, Gianpaolo Rando1,2, Clara Meda1,2, Paolo Ciana ${ }^{3}$, Luisa Ottobrini ${ }^{4}$ and Adriana Maggi1,2 \\ ${ }^{1}$ Center of Excellence on Neurodegenerative Diseases, University of Milan, Milan, Italy \\ 2Department of Pharmacological and Biomolecular Sciences, University of Milan, Milan, Italy \\ 3Department of Oncology and Hemato-Oncology, University of Milan, Milan, Italy \\ ${ }^{4}$ Department of Pathophysiology and Transplantation, University of Milan, Milan, Italy \\ Correspondence should be addressed to A Maggi: adriana.maggi@unimi.it
}

\section{Abstract}

Oestrogens are well-known proliferation and differentiation factors that play an essential role in the correct development of sex-related organs and behaviour in mammals. With the use of the ERE-Luc reporter mouse model, we show herein that throughout mouse development, oestrogen receptors (ERs) are active starting from day 12 post conception. Most interestingly, we show that prenatal luciferase expression in each organ is proportionally different in relation to the germ layer of the origin. The luciferase content is highest in ectoderm-derived organs (such as brain and skin) and is lowest in endoderm-derived organs (such as liver, lung, thymus and intestine). Consistent with the testosterone surge occurring in male mice at the end of pregnancy, in the first 2 days after birth, we observed a significant increase in the luciferase content in several organs, including the liver, bone, gonads and hindbrain. The results of the present study show a widespread transcriptional activity of ERs in developing embryos, pointing to the potential contribution of these receptors in the development of non-reproductive as well as reproductive organs. Consequently, the findings reported here might be relevant in explaining the significant differences in male and female physiopathology reported by a growing number of studies and may underline the necessity for more systematic analyses aimed at the identification of the prenatal effects of drugs interfering with ER signalling, such as aromatase inhibitors or endocrine disrupter chemicals.

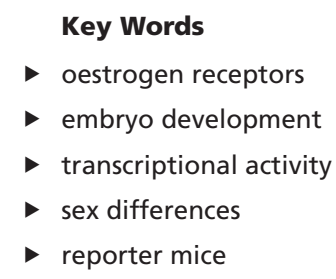

Journal of Endocrinology (2018) 238, 165-176

\section{Introduction}

Oestrogens have been long known as cell proliferation and differentiation factors (Tsai \& O'Malley 1994), and several lines of evidence suggest that, in the course of foetal programming, these hormones are relevant for the sexual differentiation of reproductive tissues, including the brain (Phoenix et al. 1959, Pang et al. 1979, Tobet et al. 1986, Korach et al. 1988, Greco et al. 1991, Rissman et al. 1997, Nielsen et al. 2000, Albrecht et al. 2009). Very little is known regarding the effects of these steroids in non-reproductive organs, in spite of the fact that preclinical and clinical investigations in subjects with prenatal impairment of ER signalling showed physiological alterations and increased incidence of diseases involving the cardiovascular (Conte et al. 1994, Jones et al. 2000, Tait et al. 2015, Yuchi et al. 2015), metabolic (Lapid et al. 2014), immune (Zoller \& Kersh 2006), respiratory (Thuresson-Klein et al. 1985), and skeletal systems as well as the epidermis (Hanley et al. 
1996, Brandenberger et al. 1997, Lemmen et al. 1999, Takeyama et al. 2001).

The biological effects of the steroid hormone $17 \beta$-oestradiol (E2) - the most expressed oestrogen - are predominantly mediated through two distinct ERs (ER $\alpha$ and ER $\beta$ ) that share a common phylogenetic origin, conserved structural organization and similar mode of action (mainly as ligand-operated transcription factors) with the other members of the nuclear receptor (NR) family (Tsai \& O'Malley 1994, Kininis \& Kraus 2008). In addition, ERs may interfere with the signalling of other membrane receptors as well as intracellular receptors, and $\mathrm{ER} \alpha$, may associate with the plasma membrane and may activate non-nuclear signalling from this site. These rapid, non-genomic/membrane initiated steroid signals have been characterized in endothelial cells but may be present in other cellular systems (Arnal et al. 2017). The functional activation of intracellular ERs occurs through binding with oestrogens, but unliganded ER activation may be triggered by enzymatic activities, inducing posttranslational modifications (Dahlman-Wright et al. 2006) that enable ER to release inhibitory proteins generally associated with inactive receptor proteins. ERs were the first NRs to be described (Toft \& Gorski 1966, Jensen 2005), and they appear to be the closest to the ancestral steroid receptor (Thornton et al. 2003). In addition to these intracellular proteins, a membrane receptor, G proteincoupled oestrogen receptor 1 (GPER1), may transduce oestrogen signals through non-genomic signalling (Revankar et al. 2005).

In adult mammals, it is well known that ERs are expressed and functionally active in most reproductive and non-reproductive tissue cells (Ciocca \& Roig 1995, Maggi et al. 2004, Bookout et al. 2006). Their expression and transcriptional activity in the course of embryo development is less studied (Brandenberger et al. 1997, Lemmen et al. 1999). In addition to selective KO mutation of $\mathrm{ER} \alpha, \mathrm{ER} \beta$ or the aromatase gene (Cyp19a1, encoding the enzyme responsible for testosterone-derived oestrogen synthesis) that highlighted the relevance of these receptors and their cognate ligands for the development of sexual organs and sexual behaviour (Kudwa et al. 2006), the elucidation of the ER distribution and activity during implantation and embryogenesis in non-reproductive tissues is circumscribed to only a few studies (Bondesson et al. 2015, Mogi et al. 2015, Park et al. 2017). However, preclinical and clinical observations in subjects carrying mutations that impair ER signalling showed deviations from the proper development of the cardiovascular system (Del Principe et al. 2015, Tait et al. 2015), innate immune and neuro-immune communications (Zoller \& Kersh 2006), pancreatic and gastric activity (Campbell-Thompson et al. 2001, Maniu et al. 2016) and liver functions (Bryzgalova et al. 2006, Foryst-Ludwig et al . 2008, Barros \& Gustafsson 2011), as well as adipose (Barros \& Gustafsson 2011, Lapid et al. 2014), lung (ThuressonKlein et al. 1985, Patrone et al. 2003, Carey et al. 2007), kidney (Lane 2008, Kummer et al. 2011) and epidermal tissues with the muscle-skeletal apparatus (Hanley et al. 1996, Brandenberger et al. 1997, Lemmen et al. 1999, Takeyama et al. 2001, Walker \& Korach 2004, Markiewicz et al. 2013, Ueberschlag-Pitiot et al. 2017).

In view of the growing number of reports pointing to significant sex-related differences in mammalian physiopathology and the increasing concern of the potential long-term effects of maternal exposure to EDCs and to drugs (such as aromatase inhibitors) that may interfere with oestrogen signalling during pregnancy, a better understanding of the oestrogen-dependent programmes in ontogeny is indispensable for the comprehension of the role of sex in the incidence of several pathologies and for the creation of efficacious protocols for the evaluation of EDCs exposure.

To verify the extent of ER transcriptional activity during embryogenesis, we investigated the luciferase expression in the ERE-Luc reporter mouse (Ciana et al. $2001,2003)$. In this mouse, the general transcription of the firefly luciferase transgene is controlled by the activated intracellular ERs. In the last 15 years, a large number of studies carried out in different laboratories showed that, in the ERE-Luc mouse, the amount of luciferase synthesized is proportional to the ER transcriptional activity and quantifiable in vivo by bioluminescence imaging or ex vivo by means of an enzymatic assay in tissue lysates (Klotz et al. 2002, Patrone et al. 2003, Humpel et al. 2005, Mussi et al. 2006, Chambliss et al. 2010, Penza et al. 2011, Vantaggiato et al. 2016). These studies demonstrated (i) a lack of interference of signals originating by the chromatin surrounding the transgene granted by the combination of the specific integration site and insulator sequences flanking the reporter (Rizzi et al. 2017), (ii) the selective response to ERs of the synthetic promoter driving luciferase transcription and (iii) that the reporter is transcriptionally viable in all tissues (as also indicated by a background reporter activity due to the TK minimal promoter).

By demonstrating that ERs are widely active during embryo development, our results will facilitate the understanding of complex functions of ERs in embryo maturation, putting novel bases for the comprehension of

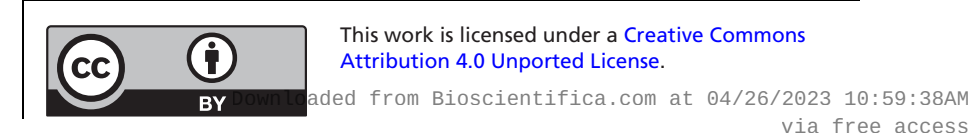


the involvement of sex in the incidence and progression of pathologies not strictly associated with reproductive functions. The data presented may also help with the prediction of the effects of exposure to EDCs or the administration of drugs, such as aromatase inhibitors to pregnant mothers. Therefore, the ERE-Luc reporter mice may be considered a valuable tool to unravel the effects of potential EDCs or drugs administered to pregnant mothers that can interfere with the oestrogen signalling of the foetus.

\section{Materials and methods}

\section{Animals}

The mice were housed with ad libitum access to standard chow (RF21, Mucedola, Italy) and water. We generated heterozygous ERE-Luc foetuses by caging homozygous ERE-Luc males with WT C57/B16j females for the night. The day after overnight mating was counted as $0.5 \mathrm{dpc}$ (day post conception). Natural birth occurred on $19.5 \mathrm{dpc}$, which was counted as day 0 post birth (P0). In the experiments with the knockouts, the mice heterozygous for aromatase $(\mathrm{Ar}+/-)$ from E. Simpson were crossed with ERE-Luc mice, and the progeny were as backcrossed to obtain both KO and WT foetuses in the same litter that were genotyped from tail-derived DNA by PCR using published primers (Fisher et al. 1998). The sex was confirmed by PCR of the SMC locus (Agulnik et al. 1997). All the animal experiments were carried out in accordance with the European Guidelines for human animal care. The use of experimental animals was approved by the Italian Ministry of Research and University and was controlled by the panel of experts of the Department of Pharmacological and Biomolecular Sciences at the University of Milan.

\section{Treatment with ER antagonist}

ICI 182,780 powder (Sigma) was dissolved in $99 \% \mathrm{v} / \mathrm{v}$ ethanol to a concentration of $30 \mathrm{mg} / \mathrm{mL}$. A total of $75 \mu \mathrm{g}$ or $30 \mu \mathrm{g}$ of ICI, dispersed in $100 \mu \mathrm{L}$ of maize oil, was s.c. injected $24 \mathrm{~h}$ and $6 \mathrm{~h}$ before the imaging session, resulting in $1 \mathrm{mg} / \mathrm{kg}$ and $2.5 \mathrm{mg} / \mathrm{kg}$ for a $33 \mathrm{~g}$ female at day $\sim 16$ of pregnancy.

\section{In vivo bioluminescence imaging}

Pregnant females were anaesthetized with $50 \mu \mathrm{L}$ s.c. injection of a water solution of $78 \%$ ketamine (Ketavet $50 \mathrm{mg} / \mathrm{mL}$, Intervet, Peschiera Borromeo, Italy) and

$$
\begin{aligned}
& \text { http://joe.endocrinology-journals.org } \\
& \text { https://doi.org/10.1530/JOE-18-0003 }
\end{aligned}
$$

$15 \%$ xylazine (Rompun $20 \mathrm{mg} / \mathrm{mL}$, Bayer, Leverkusen, Germany). Once anaesthetized, the pregnant females were shaved to allow a better measurement of the photons emitted from the foetuses. Fifteen minutes before BLI, $90 \mu \mathrm{L}$ of a water solution of the luciferase substrate luciferin (Beetle luciferin potassium salt, Promega) was administered s.c. $(75 \mathrm{mg} / \mathrm{kg})$. Bioluminescence was measured by a Night Owl imaging unit (Berthold Technologies, Bad Wildbad, Germany); the mice were placed in the light-tight chamber, and their pictures were first taken with dimmed light, and then the luciferase signal was registered for $5 \mathrm{~min}$. Merging of the images enabled to visualizing body areas where photon emission occurred (luciferase signal was transformed in pseudocolours: blue-lowest, then green, red, yellow and white as the highest signal). For quantification, photon emission was measured in the whole body areas (counts per second, cts/s). Normalization was performed using an external source of photons (Glowell, Lux Biotechnology, Edinburgh, UK) enabling measurement of the instrumental efficiency of photon counting. All the measurements were performed using WinLight32 (Berthold Technologies). After BLI, the foetuses were dissected under binocular macroscopy, and the organs shown in the figures were collected, frozen on dry-ice and stored at $-80^{\circ} \mathrm{C}$ until assayed.

\section{Luciferase enzymatic assay}

The tissues were homogenized in $200 \mu \mathrm{L}$ ice-cold lysis buffer $\left(100 \mathrm{mM} \mathrm{KPO}_{4}, 1 \mathrm{mM}\right.$ DTT, $4 \mathrm{mM}$ EGTA, $4 \mathrm{mM}$ EDTA, pH 7.8) with a micro pestle (Eppendorf); then, they underwent freezing and were thawed during centrifugation at $4900 \mathrm{~g}, 4^{\circ} \mathrm{C}$ for $25 \mathrm{~min}$. The supernatants were collected, and the protein concentrations were measured by Bradford assay following the manufacturer's instructions (Pierce Biotech). Luciferase enzymatic activity was measured with a commercial kit (Luciferase Assay System, Promega) in a luminometer (Glomax, Promega) and was expressed as the relative light units over $10 \mathrm{~s} / \mathrm{\mu g}$ protein (RLU/ug proteins).

\section{Immunohistochemistry}

The mice at $17.5 \mathrm{dpc}$ were fixed in $4 \%$ paraformaldehyde, embedded in paraffin and whole-sliced. Sections of $5 \mu \mathrm{m}$ were deparaffinized in xylene and rehydrated in decreasing ethanol concentrations. After washing, the slides were microwaved in citrate buffer, washed in PBS and incubated 15 min in $1 \% \mathrm{H}_{2} \mathrm{O}_{2}$.

This work is licensed under a Creative Commons Attribution 4.0 Unported License. 
For luciferase detection: After three PBS washes, the sections were permeabilized in $0.2 \%$ Triton-X-100 in PBS and blocked by incubation with $10 \%$ goat serum and $0.3 \%$ Tween 20 in PBS for $30 \mathrm{~min}$ at $37^{\circ} \mathrm{C}$, followed by biotin blocking buffer (Vector Laboratories). The sections were incubated in a humidity chamber overnight at $4^{\circ} \mathrm{C}$ with rabbit anti-luciferase antibody or normal rabbit serum diluted 1:6000 in blocking buffer. The anti-luciferase antibody was provided by W Just (Soto et al. 1993). Next, the sections were washed in 0.3\% Tween 20 PBS and were incubated at room temperature for $60 \mathrm{~min}$ with biotinylated goat anti-rabbit IgG (Vector Laboratories) and diluted 1:200 in 1\% normal goat serum $0.3 \%$ Tween 20. Detection was performed with the Vectastain ABC kit (Vector Laboratories) according to the manufacturer's instructions. The sections were counterstained with haematoxylin/eosin.

For ER $\alpha$ detection: After three PBS washes, the sections were permeabilized and blocked by incubation with $10 \%$ goat serum, $0.3 \%$ Triton-X in PBS for $120 \mathrm{~min}$ at RT, followed by biotin blocking buffer (Vector Laboratories). The sections were then incubated in a humidity chamber overnight at $4^{\circ} \mathrm{C}$ with anti-ER $\alpha$ antibody (polyclonal, made in rabbit, Abcam ab75635) or normal rabbit serum was diluted 1:100 in blocking buffer. Next, the sections were washed in 0.3\% Tween 20 PBS and were incubated at room temperature for $60 \mathrm{~min}$ with biotinylated goat anti-rabbit IgG (Vector Laboratories), diluted 1:200 in 1\% normal goat serum. Detection was performed with the Vectastain ABC kit (Vector Laboratories) according to the manufacturer's instructions.

\section{Statistical analysis}

$P$ values were calculated as described in the figure legends using GraphPad Prism version 5.01 for Windows, GraphPad Software.

\section{Results}

The in vivo BLI of WT female mice crossed with homozygote male ERE-Luc clearly showed luciferase activity in living foetuses growing in utero. Figure $1 \mathrm{~A}$ shows that by exposing the pregnant mothers to CCD, photon emission from the foetuses was measurable from 14.5 days post conception (dpc), increasing in the course of pregnancy and was highest at $18.5 \mathrm{dpc}$. Considering that the mother tissues shielded some of the embryo bioluminescence, to obtain better insight into the onset of luciferase synthesis in the embryos, we investigated the BLI pattern of ER activity in excised embryos.
A
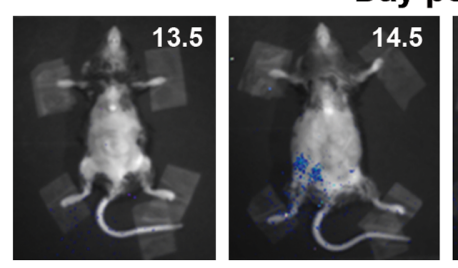

Day post conception (dpc)

\section{B}
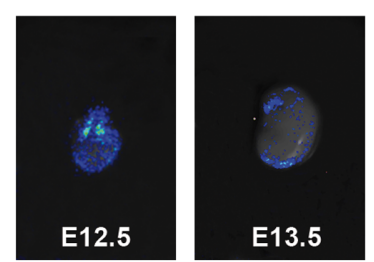

Developmental stage
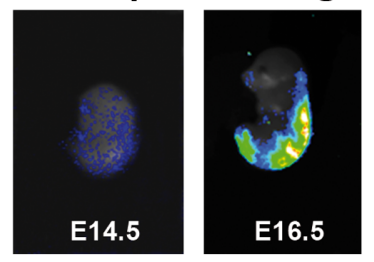
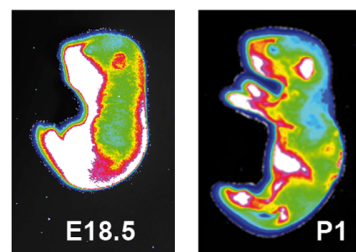

C
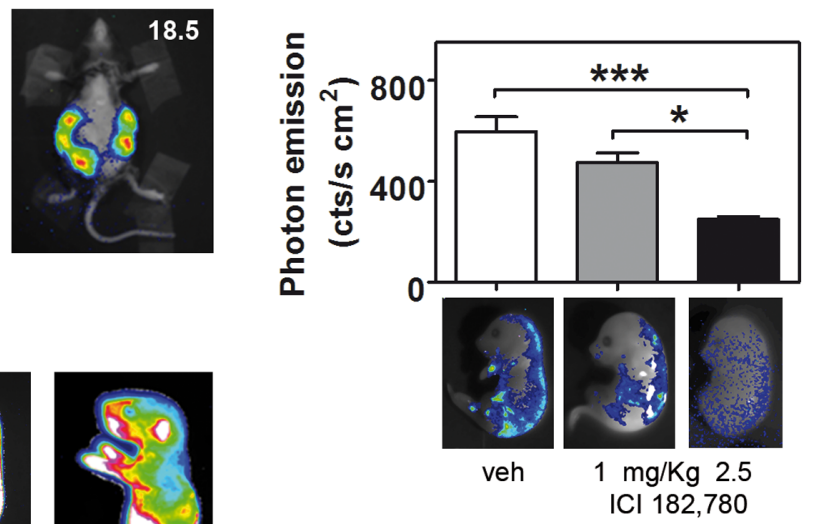

ICl 182,780

Figure 1

ER is transcriptionally active in the developing mouse. (A) In utero imaging: anaesthetized WT pregnant mothers carrying ERE-Luc foetuses were injected with the substrate luciferin 30 min prior to imaging, and photon emission was recorded in BLI units. Merging of the pseudo colour-transformed signal with the pregnant picture allows the identification of transcriptional active oestrogen receptors in the developing litter (blue: low, white: high). The mothers were shaved to improve photon imaging. (B) Representative BLI taken in living foetuses immediately after uterine excision and of a newborn mouse at P1. The sex of the mouse at P1 is male. (C) $24 \mathrm{~h}$ and $6 \mathrm{~h}$ before litter collection, pregnant females were treated with vehicle or $1 \mathrm{mg} / \mathrm{kg}$ or $2.5 \mathrm{mg} / \mathrm{kg}$ of the ER pure antagonist ICI 182,780. Foetuses were excised at $16.5 \mathrm{dpc}$ and were subjected to BLI. Photon emission (cts/cm² s) was measured in the whole (upper) foetal area and was transformed in a pseudocolour image merged on the mice pictures (lower). Bars represent the mean \pm s.E.M. $\star P<0.05$ calculated with one-way ANOVA followed by Bonferroni post hoc test.

http://joe.endocrinology-journals.org https://doi.org/10.1530/JOE-18-0003
() 2018 The authors Published by Bioscientifica Ltd. Printed in Great Britain

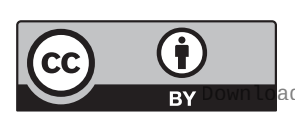

This work is licensed under a Creative Commons Attribution 4.0 Unported License. ed from Bioscientifica.com at 04/26/2023 10:59:38AM 
Therefore, the mothers were injected with luciferin and killed for the dissection and rapid measurement of BLI in each individual embryo (Fig. 1B). Photon emission was measurable starting at $12.5 \mathrm{dpc}$ but not before. At $12.5 \mathrm{dpc}$, photon emission was quite diffuse in the whole embryo, with higher emission in the telencephalon, in the proximity of the eyes, in the heart and in the spinal ganglia. The finding of luciferase activity at $12.5 \mathrm{dpc}$ was consistent with gonad differentiation from a bipotential to sexually differentiated state (as indicated by transcriptome analysis) (Munger et al. 2013) and with the highest foetal production of oestrogens (Lemmen et al. 2002). At $13.5 \mathrm{dpc}$, photon emission was more circumscribed to the brain and peripheral nervous system. From $16.5 \mathrm{dpc}$ to $18.5 \mathrm{dpc}$, luciferase emission increased from the dorsal to the ventral skin, and one day post birth (P1), the signal was maximal in the hepatic/abdomen area and in the limbs.

To rule out that oestrogen-related receptors (ERRs), which are widely expressed in embryos (Bonnelye et al. 1997, Luo et al. 1997), were active on the promoter of the ERE-Luc mouse, we treated pregnant females with the ER pan-antagonist fulvestrant (ICI 182,780), which has been reported to be an agonist of ERRs (Li et al. 2010). Treatment of the mothers with $1 \mathrm{mg} / \mathrm{kg}$ and $2.5 \mathrm{mg} / \mathrm{kg}$ ICI 182,780 was associated with a dose-dependent decrease in photon emission in foetuses (Fig. 1C), pointing to the absence of significant contributions from ERRs to luciferase synthesis. To further demonstrate the strict association between photon emission and ER-dependent luciferase expression, mice at $17.5 \mathrm{dpc}$ were subjected to BLI and were subsequently whole-mounted for staining with anti-luciferase antibodies. The intensity and distribution of the peroxidase staining clearly reproduced the BLI (Fig. 2A and B) and enabled the definition of the cells expressing the reporter enzyme at the cellular level. The specificity of the luciferase staining was tested in several tissues of ERE-Luc and WT mice (Fig. 2C, D, E, F, $\mathrm{G}, \mathrm{H}$ and I) and, importantly, the immuno-decoration of luciferase reproduced the staining obtained with anti-ER $\alpha$ antibodies in several tissues (whole snout, muscle, bone, whiskers, skin) (Fig. 2L, M, N, O and P).

This experiment, together with previous BLI observations, was a clear indication of the widespread ER transcriptional activity. In addition to brain and reproductive organs, we found significant amounts of luciferase activity in several non-reproductive tissues. The overall analysis of luciferase showed very high staining in the epidermis and in the hindbrain. With regard to the other organs, the staining appeared to follow a gradient: highest in ectoderm-derived organs and lowest in endodermal organs.

BLI, enabling the measurement of the reporter activity in living animals, is extremely useful for the spatio-temporal study of a given molecular event in single individuals; however, the two dimensional nature of the BLI outcome does not allow the exact, quantitative localization of the organ responsible for photon emission, as the deeper an organ is, the more attenuated the BLI signal, and the photon emission measured in a specific surface represents the sum of all signals coming from the different layers of tissue (Maggi \& Ciana 2005). Thus, to better define the organs where ERs were most active, we carried out a series of enzymatic assays in selected tissue extracts. The measured luciferase activity changed significantly in the different organs and ranged from $10 \mathrm{RLU} / \mu \mathrm{g}$ protein to $4000 \mathrm{RLU} / \mu \mathrm{g}$ protein. In line with what was suggested by prior immunohistochemistry analyses, we found a strict correlation between the germ layer and the amount of luciferase activity (Fig. 3). The highest expression of the reporter was found in ectodermderived organs (brain and skin), while in the endodermderived organs (liver, lung, thymus and intestine), ER activity was the lowest. Mesodermic organs (heart, femur, gonad and kidney) appeared to have an intermediate concentration of the enzyme. Supplementary Figure 1 (see section on supplementary data given at the end of this article) shows that in the skin, hindbrain and forebrain, luciferase is, in general, statistically more expressed than in the other tissues.

Next, we stratified the data in relation to sex (Fig. 4). No major differences were found prior to birth. The only exception was represented by the gonads at $18.5 \mathrm{dpc}$, where females had more luciferase than males, an effect possibly associated with the very high expression of ER $\alpha$ protein in the ovary (Nielsen et al. 2000) at this embryonal stage. At P1, there was a generalized increase in luciferase activity in most organs. In the liver, bone, gonads and hindbrain, the increase observed in luciferase expression was significantly higher in males.

This result was consistent with the fact that male, not female, gonads synthesize steroids just prior to and after birth and that the testosterone synthesized is aromatized to E2 in several organs (Jones et al. 2000). When we crossed the ERE-Luc with the aromatase KO mice, we failed to see such an effect in male livers and femurs as well as the testis and skin of pups at P1 (Fig. 5). In the ArKOxERELuc mice, the luciferase activity was comparable with the levels recorded through previous foetal stages (Fig. 3; RLU/ug protein: liver $5.67 \pm 1.33$; femur $42.67 \pm 9.28$; testis $6.67 \pm 3.67$; skin $572 \pm 75.50$ ), which provided further 


\begin{tabular}{|l|l|l|l|l|}
\hline $\begin{array}{l}\text { Journal of } \\
\text { Endocrinology }\end{array}$ & S Della Torre et al. & $\begin{array}{l}\text { ER activity during embryo } \\
\text { development }\end{array}$ & $\mathbf{2 3 8 : 3}$ & $\mathbf{1 7 0}$ \\
\hline
\end{tabular}
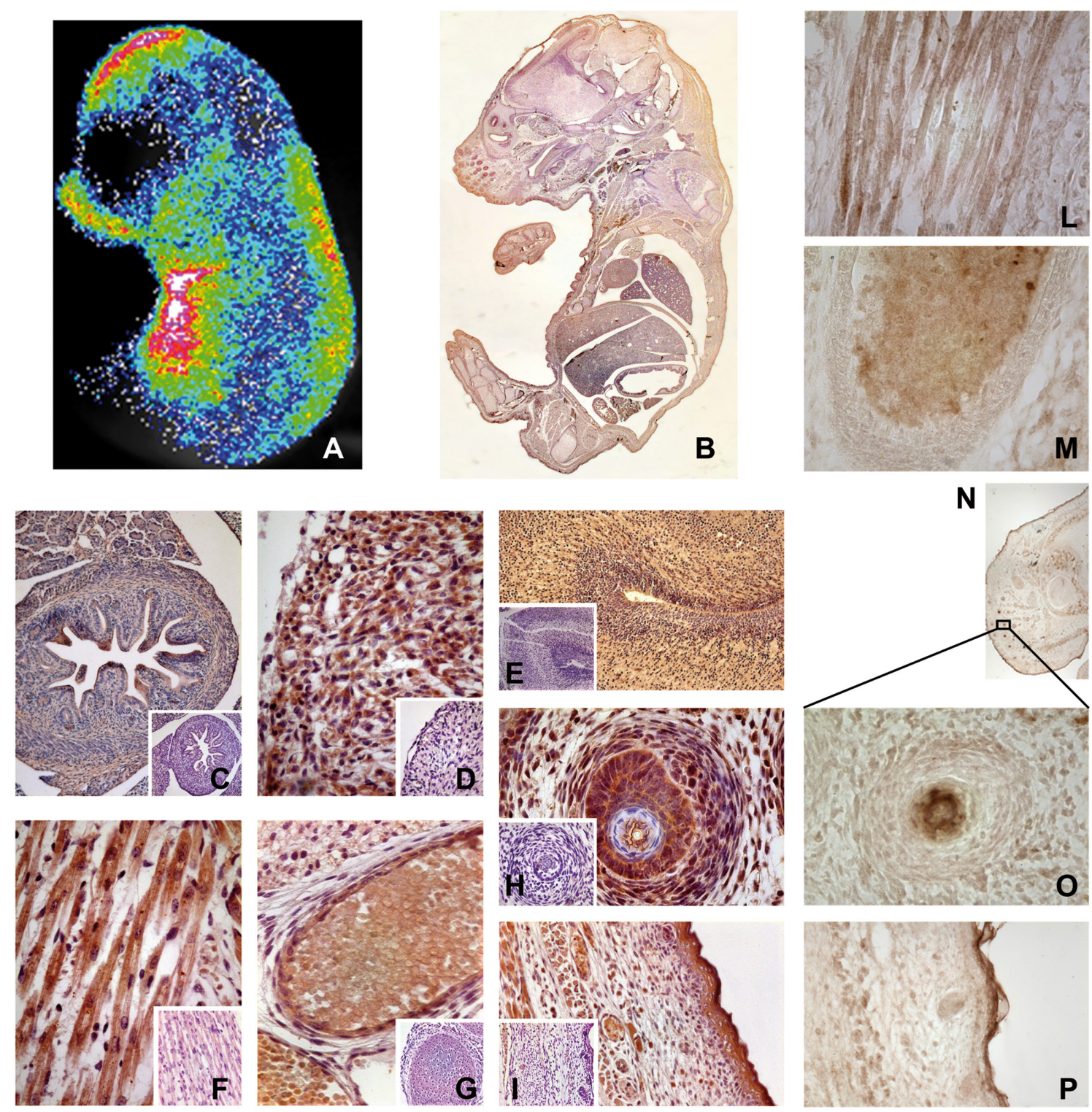

\section{Figure 2}

Immunostaining reveals ER activity in different tissues. A $17.5 \mathrm{dpc}$ litter was subjected both to BLI and to IHC against luciferase and ER $\alpha$.

(A) Representative BLI of one mouse (signal was arithmetically increased with respect to Fig. 1B) and one of its whole-mount sections stained for luciferase (B). (C, D, E, F, G, H and I) IHC against luciferase; organ pictures were taken at 100-400x magnification: intestine (C; 100x), heart (D; 400x), hindbrain $(E ; 100 x)$, muscle $(F ; 400 x)$, rib $(G ; 400 x)$, whisker follicle $(H ; 400 x)$, skin $(I ; 200 x)$. Small panels show the antibody specificity tested on a WT mouse. (L, M, N, O and P) IHC against ER $\alpha$; organ pictures were taken at 100-400x magnification: muscle (L; 400x), rib (M; 400x), nose (N; reconstruction of 50x), whisker follicle $(0 ; 400 x)$, skin (P; 200x).

support for the hypothesis that the increased activity of the reporter observed in males only at P1 was induced by the oestrogens derived from the surge of testosterone production by male gonads (Clarkson \& Herbison 2016). In addition, the observation of a basal level of ER activity in the different organs of ArKOxERE-Luc mice suggested that the unliganded ERs could be activated by factors other than circulating oestrogens. Printed in Great Britain

\section{Discussion}

The present study demonstrates that, in the course of embryogenesis, ER transcriptional activity is not restricted to the reproductive organs. Indeed, ERs appear to be particularly active in tissues originating from the ectoderm, such as the brain and skin and have a lower yet still significant action in tissues, such as the gonads,

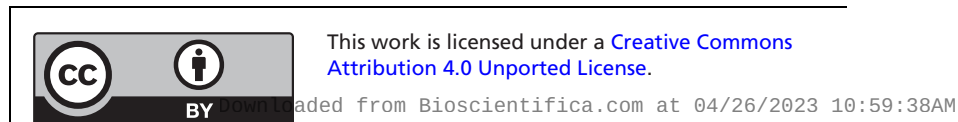


Endoderm

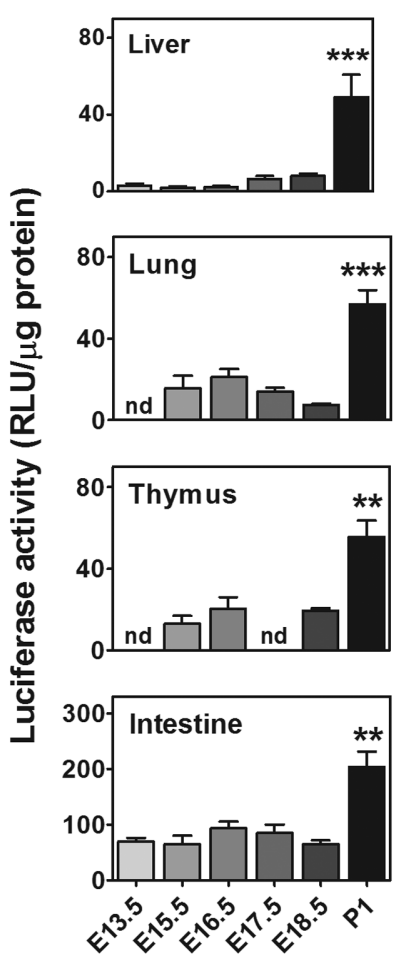

Mesoderm
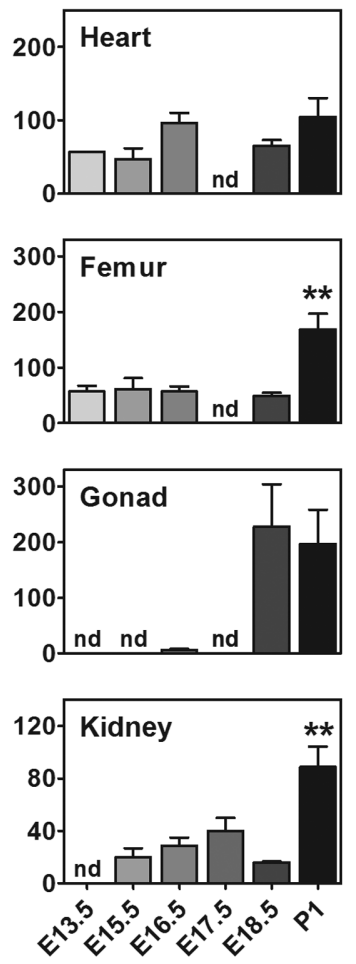

Ectoderm
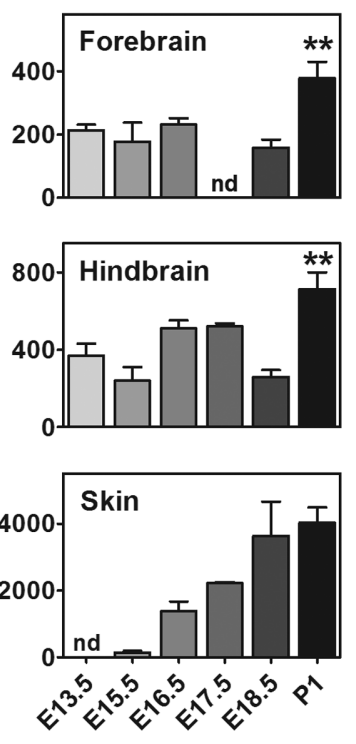

Figure 3

Foetal ER activity shows lineage-correlation. A pattern of ER transcriptional activity in different organs was obtained by measuring the luciferase activity on tissue lysates (enzymatic assay) obtained from the foetuses of both sexes. Each column contains organs from different germ layers. Bars represent the mean \pm S.E.M. $(n=6-10$ foetuses). ${ }^{*} P<0.05, * * P<0.01$ vs the previous stage calculated by one-way ANOVA followed by the Bonferroni post hoc test. nd, not measured. kidney, bone and hearth, deriving from the mesoderm. Quite interesting is the fact that ERs are minimally active in endodermic tissues, such as the lung, liver, thymus and intestine.

The mechanisms associated with this differential pattern of ER activity in the organs studied in relation to the germ-layer of origin remain to be defined. An initial explanation could be associated with a differential, tissuespecific expression of the two isoforms of ER. The lack of a detailed localization study describing the relative content of $\mathrm{ER} \alpha$ and $\mathrm{ER} \beta$ in embryogenesis does not allow us to define whether the differences of ER activity observed are due to a germ-layer-specific expression of each ER or to changes in their relative concentration with consequent potential homo- or hetero-dimerization. A second potential explanation resides in ligand availability, as it is conceivable that, depending of the stage of development, the oestrogens produced may have differential ability to reach the organs deriving from each of the three germ layers. The main source of steroid hormones during pregnancy is the maternal-placental-foetal unit (MPF unit) (Becker 2001). Measurements of oestrogen concentration in maternal blood showed a steady increase throughout pregnancy, with a peak at 17.5 dpc (Barkley et al. 1977); in the foetus, the peak of oestrogen synthesis is at $12.5 \mathrm{dpc}$ (Lemmen et al. 2002). However, to be transported by the plasma, these lipophilic molecules associate with the alpha-fetoprotein (AFP), and it has been hypothesized that the high concentration of AFP produced may sequester most of the steroids produced by the MPF and may protect the foetus from the effects of maternal steroid hormones (Savu et al. 1981, Mendel 1989, Bakker et al. 2006, De Mees et al. 2006). Our data clearly show a germ layerdependent ER transcriptional activity, which that could be due to either the existence of a tissue-specific uptake of circulating oestrogens or to ER unliganded activation. Indeed, endocytic pathways were described as necessary to carry steroids inside the cells (Hammes et al. 2005), but we still do not know whether such transport proteins are present in the embryo and are localized differentially in the various tissues. Alternatively, ERs may be differentially activated by means of a localized pattern of expression of genes encoding factors known to be able to activate these NRs in a unliganded way (such as EGF, IGF or others) (Bondy et al. 1990, Partanen 1990).

Regardless of the mechanisms involved, the number of tissues where ER is transcriptionally active in the course of development is suggestive of a significant biological function of the hormone-receptor complex in both reproductive and non-reproductive organs. Unfortunately, the developmental effects of the deletion of genes encoding $\operatorname{ER} \alpha$ and $\operatorname{ER} \beta$ or both isoforms have been only slightly investigated. This lack of study is possibly due the fact that none of the initial studies

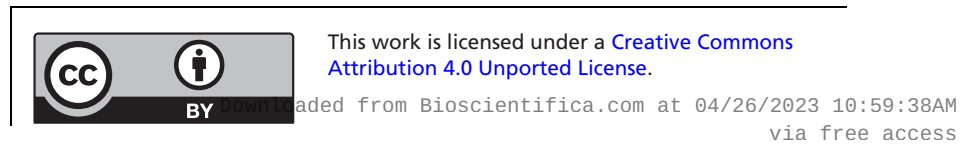


Endoderm

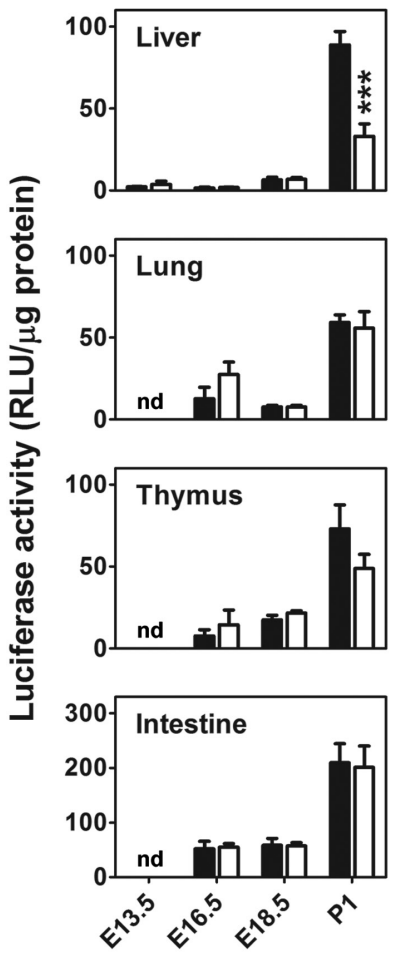

Mesoderm
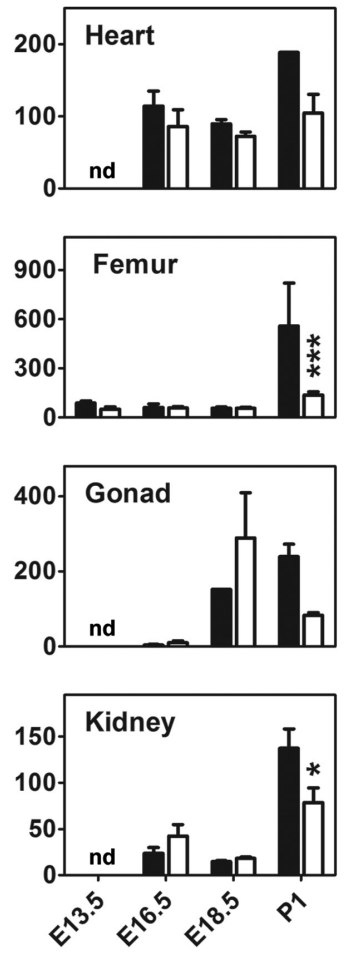

\section{Ectoderm}
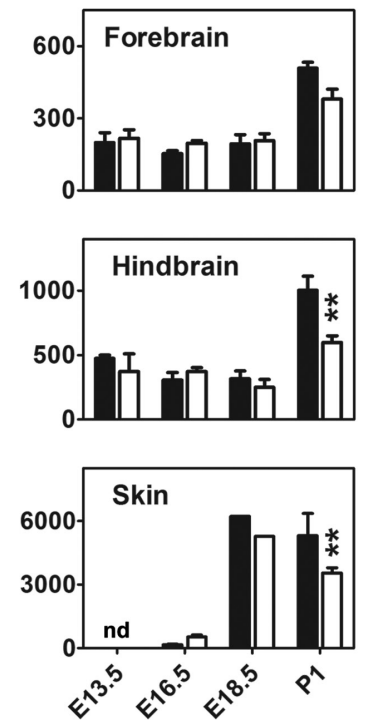

\section{Figure 4}

Gender specificity in ER activity during development. The same data shown in Fig. 3 (luciferase enzymatic assay) were stratified for sex. Bars represent the mean \pm s.E.M. $(n=4-6)$. ${ }^{*} P<0.05,{ }^{*} P<0.01$ compared with opposite gender calculated with unpaired Student's $t$ test. nd, not measured. described major phenotypes, and both males and females survived to adulthood (Lubahn et al. 1993, Krege et al. 1998, Couse et al. 1999), even with fertility problems, which is particularly relevant in the ER $\alpha$-null mice (Krege et al. 1998, Dupont et al. 2000, Walker \& Korach 2004). However, more recent studies carried out in adults demonstrated that the deletion of ER $\alpha$ or ER $\beta$ is associated with malfunctions of several organs considered to be non-essential for reproduction, such as the lung, liver, adipose tissue, heart, kidney, thymus, bone and skin (Brandenberger et al. 1997, Lemmen et al. 1999, Takeyama et al. 2001, Walker \& Korach 2004, Zoller \& Kersh 2006, Carey et al. 2007, Foryst-Ludwig et al. 2008, Barros \& Gustafsson 2011, Kummer et al. 2011, Markiewicz et al. 2013, Lapid et al. 2014, Del Principe et al. 2015, Tait et al. 2015). In the perinatal mouse brain, the spatio-temporal expression of $\mathrm{ER} \alpha$ and $\mathrm{ER} \beta$ was reported to contribute to organize sex differences that are not associated with
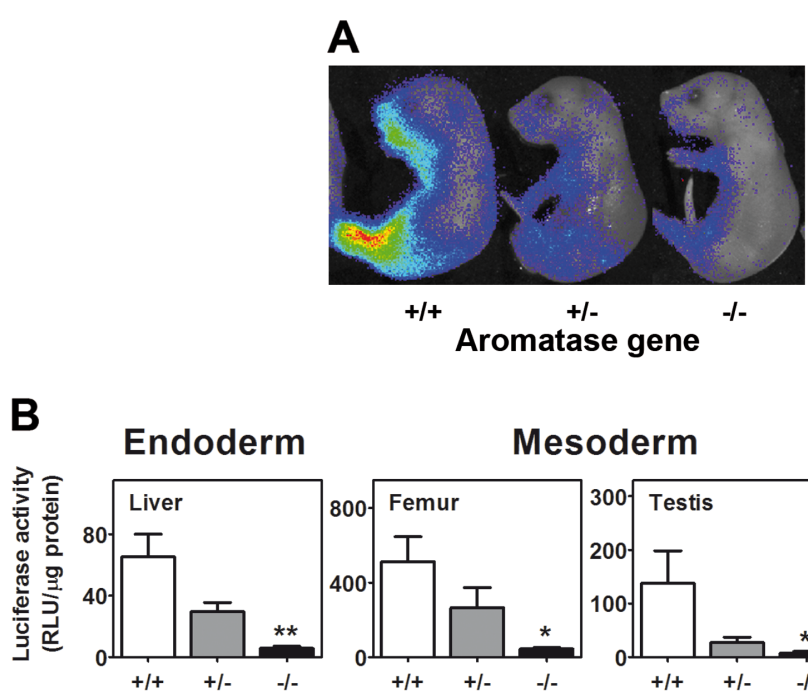

Mesoderm

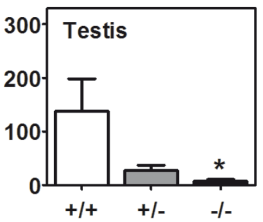

Aromatase gene

\section{Figure 5}

Lack of aromatase activity regulates ER activity in males. ERE-Luc mice were bred with $\mathrm{Ar}+$ /- mice, and the progeny was backcrossed to obtain the same litter $\mathrm{Ar}-/-$ and $\mathrm{Ar}+/+\times$ ERE-Luc mice. (A) Newborn P1 mice were subjected to BLI. (B) Luciferase activity was measured in tissue lysates (enzymatic assay) in which gender difference was previously observed (Fig. 4). Bars represent the mean \pm S.E.M. $\left(n=4-6\right.$ foetuses). ${ }^{*} P<0.05, * * P<0.01$ vs $\mathrm{Ar}+/+\times$ ERE-Luc calculated by one-way ANOVA followed by Bonferroni post hoc test.

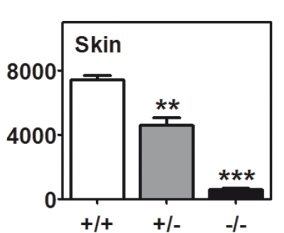

This work is licensed under a Creative Commons Attribution 4.0 Unported License. 
reproduction, such as the stress response and cognition (Mogi et al. 2015).

It is conceivable that the sexual dimorphism observed in the prevalence, course and severity of many common diseases, including cardiovascular diseases, autoimmune diseases and asthma, may originate from a sex-specific genetic architecture that is created in the course of development (also through ER activity) and that results in a male and female differential endocrine susceptibility and gene regulation, particularly in sex steroid-responsive genes. The relevance of oestrogen programming mechanisms within the mammalian foetus and perinatal time period is underlined by studies on liver metabolism that are strictly regulated by sex and where the expression and activation of hepatic ER in the course of embryo maturation and in adult life plays a prominent role (Della Torre et al. 2018) on energy metabolism (Yuchi et al. 2015, Maniu et al. 2016), gastric functions (Campbell-Thompson et al. 2001), adrenal and renal activity (Walker et al. 2009, Inamdar et al. 2015), cardiovascular activity (Del Principe et al. 2015) and immune functions (Zoller \& Kersh 2006).

In conclusion, the results from this study and those mentioned above point to a substantial relevance of ER signalling for the correct development of mammalian embryos, and they highlight the necessity to increase our knowledge with more systematic studies aimed at understanding the necessity of these hormones, particularly for the correct development and functioning of non-reproductive organs. Such studies should not be confined to prenatal development and pups, but should be extended to adults, possibly challenged with appropriate stimuli, enabling us to test their ability to respond to alimentary and environmental stimuli, with a particular emphasis onto endocrine disrupters known to preferentially act through ERs.

\section{Supplementary data}

This is linked to the online version of the paper at https://doi.org/10.1530/ JOE-18-0003.

\section{Declaration of interest}

The authors declare that there is no conflict of interest that could be perceived as prejudicing the impartiality of the research reported.

\section{Funding}

This work was supported by grants from the European Community (EWA: STREP EWA LSHM-CT-2005-518245; Ways: ERC-Advanced Grant 322977) and NIH (RO1-AF027713).

\section{Author contribution statement}

S D T carried out all the final analyses and control experiments. G R carried out most of the experimental work, together with L O. C M performed the immunostaining experiments. P C contributed in conceiving the study and shared his expertise on the use of ERE-Luc mice. A M conceived the project, wrote the manuscript and supervised the entire project.

\section{Acknowledgements}

The authors thank E Simpson (Monash University, Victoria, Australia) for providing the transgenic mice. They acknowledge E Faggiani and $\mathrm{M}$ Rebecchi for their skilful technical assistance during genotyping.

\section{References}

Agulnik AI, Bishop CE, Lerner JL, Agulnik SI \& Solovyev VV 1997 Analysis of mutation rates in the SMCY/SMCX genes shows that mammalian evolution is male driven. Mammalian Genome 8 134-138. (https://doi.org/10.1007/s003359900372)

Albrecht ED, Lane MV, Marshall GR, Merchenthaler I, Simorangkir DR, Pohl CR, Plant TM \& Pepe GJ 2009 Estrogen promotes germ cell and seminiferous tubule development in the baboon fetal testis. Biology of Reproduction 81 406-414. (https://doi.org/10.1095/ biolreprod.108.073494)

Arnal JF, Lenfant F, Metivier R, Flouriot G, Henrion D, Adlanmerini M, Fontaine C, Gourdy P, Chambon P, Katzenellenbogen B, et al. 2017 Membrane and nuclear estrogen receptor alpha actions: from tissue specificity to medical implications. Physiological Reviews $\mathbf{9 7}$ 1045-1087. (https://doi.org/10.1152/physrev.00024.2016)

Bakker J, De Mees C, Douhard Q, Balthazart J, Gabant P, Szpirer J \& Szpirer C 2006 Alpha-fetoprotein protects the developing female mouse brain from masculinization and defeminization by estrogens. Nature Neuroscience 9 220-226. (https://doi.org/10.1038/nn1624)

Barkley MS, Michael SD, Geschwind, II \& Bradford GE 1977 Plasma testosterone during pregnancy in the mouse. Endocrinology $\mathbf{1 0 0}$ 1472-1475. (https://doi.org/10.1210/endo-100-5-1472)

Barros RP \& Gustafsson JA 2011 Estrogen receptors and the metabolic network. Cell Metabolism 14 289-299. (https://doi.org/10.1016/j. cmet.2011.08.005)

Becker KL 2001 Principles and Practice of Endocrinology and Metabolism. Philadelphia, PA, USA: Lippincott Williams \& Wilkins.

Bondesson M, Hao R, Lin CY, Williams C \& Gustafsson JA 2015 Estrogen receptor signaling during vertebrate development. Biochimica et Biophysica Acta 1849 142-151. (https://doi.org/10.1016/j. bbagrm.2014.06.005)

Bondy CA, Werner H, Roberts CT Jr \& LeRoith D 1990 Cellular pattern of insulin-like growth factor-I (IGF-I) and type I IGF receptor gene expression in early organogenesis: comparison with IGF-II gene expression. Molecular Endocrinology 4 1386-1398. (https://doi. org/10.1210/mend-4-9-1386)

Bonnelye E, Vanacker JM, Spruyt N, Alric S, Fournier B, Desbiens X \& Laudet V 1997 Expression of the estrogen-related receptor 1 (ERR-1) orphan receptor during mouse development. Mechanisms of Development 65 71-85. (https://doi.org/10.1016/S09254773(97)00059-2)

Bookout AL, Jeong Y, Downes M, Yu RT, Evans RM \& Mangelsdorf DJ 2006 Anatomical profiling of nuclear receptor expression reveals a hierarchical transcriptional network. Cell 126 789-799. (https://doi. org/10.1016/j.cell.2006.06.049)

Brandenberger AW, Tee MK, Lee JY, Chao V \& Jaffe RB 1997 Tissue distribution of estrogen receptors alpha (ER-alpha) and beta (ER-beta) mRNA in the midgestational human foetus. Journal of Clinical

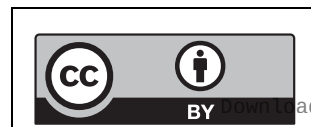

This work is licensed under a Creative Commons Attribution 4.0 Unported License. 
Endocrinology and Metabolism 82 3509-3512. (https://doi.org/10.1210/ jcem.82.10.4400)

Bryzgalova G, Gao H, Ahren B, Zierath JR, Galuska D, Steiler TL Dahlman-Wright K, Nilsson S, Gustafsson JA, Efendic S, et al. 2006 Evidence that oestrogen receptor-alpha plays an important role in the regulation of glucose homeostasis in mice: insulin sensitivity in the liver. Diabetologia 49 588-597. (https://doi.org/10.1007/s00125-0050105-3)

Campbell-Thompson M, Reyher KK \& Wilkinson LB 2001 Immunolocalization of estrogen receptor alpha and beta in gastric epithelium and enteric neurons. Journal of Endocrinology 171 65-73. (https://doi.org/10.1677/joe.0.1710065)

Carey MA, Card JW, Bradbury JA, Moorman MP, Haykal-Coates N, Gavett SH, Graves JP, Walker VR, Flake GP, Voltz JW, et al. 2007 Spontaneous airway hyperresponsiveness in estrogen receptoralpha-deficient mice. American Journal of Respiratory and Critical Care Medicine 175 126-135. (https://doi.org/10.1164/rccm.20050914930C)

Chambliss KL, Wu Q, Oltmann S, Konaniah ES, Umetani M, Korach KS, Thomas GD, Mineo C, Yuhanna IS, Kim SH, et al. 2010 Non-nuclear estrogen receptor alpha signaling promotes cardiovascular protection but not uterine or breast cancer growth in mice. Journal of Clinical Investigation 120 2319-2330. (https://doi.org/10.1172/JCI38291)

Ciana P, Di Luccio G, Belcredito S, Pollio G, Vegeto E, Tatangelo L, Tiveron C \& Maggi A 2001 Engineering of a mouse for the in vivo profiling of estrogen receptor activity. Molecular Endocrinology 15 1104-1113. (https://doi.org/10.1210/mend.15.7.0658)

Ciana P, Raviscioni M, Mussi P, Vegeto E, Que I, Parker MG, Lowik C \& Maggi A 2003 In vivo imaging of transcriptionally active estrogen receptors. Nature Medicine 9 82-86. (https://doi.org/10.1038/nm809)

Ciocca DR \& Roig LM 1995 Estrogen receptors in human nontarget tissues: biological and clinical implications. Endocrine Reviews $\mathbf{1 6}$ 35-62. (https://doi.org/10.1210/edrv-16-1-35)

Clarkson J \& Herbison AE 2016 Hypothalamic control of the male neonatal testosterone surge. Philosophical Transactions of the Royal Society of London: Series B, Biological Sciences 371 20150115. (https:// doi.org/10.1098/rstb.2015.0115)

Conte FA, Grumbach MM, Ito Y, Fisher CR \& Simpson ER 1994 A syndrome of female pseudohermaphrodism, hypergonadotropic hypogonadism, and multicystic ovaries associated with missense mutations in the gene encoding aromatase (P450arom). Journal of Clinical Endocrinology and Metabolism 78 1287-1292. (https://doi. org/10.1210/jcem.78.6.8200927)

Couse JF, Hewitt SC, Bunch DO, Sar M, Walker VR, Davis BJ \& Korach KS 1999 Postnatal sex reversal of the ovaries in mice lacking estrogen receptors alpha and beta. Science $\mathbf{2 8 6} 2328-2331$. (https://doi. org/10.1126/science.286.5448.2328)

Dahlman-Wright K, Cavailles V, Fuqua SA, Jordan VC, Katzenellenbogen JA, Korach KS, Maggi A, Muramatsu M, Parker MG \& Gustafsson JA 2006 International Union of Pharmacology. LXIV. Estrogen receptors. Pharmacological Reviews 58 773-781. (https://doi. org/10.1124/pr.58.4.8)

De Mees C, Laes JF, Bakker J, Smitz J, Hennuy B, Van Vooren P, Gabant P, Szpirer J \& Szpirer C 2006 Alpha-fetoprotein controls female fertility and prenatal development of the gonadotropin-releasing hormone pathway through an antiestrogenic action. Molecular and Cellular Biology 26 2012-2018. (https://doi.org/10.1128/МСB.26.5.20122018.2006)

Del Principe D, Ruggieri A, Pietraforte D, Villani A, Vitale C, Straface E \& Malorni W 2015 The relevance of estrogen/estrogen receptor system on the gender difference in cardiovascular risk. International Journal of Cardiology 187 291-298. (https://doi.org/10.1016/j. ijcard.2015.03.145)

Della Torre S, Mitro N, Meda C, Lolli F, Pedretti S, Barcella M, Ottobrini L, Metzger D, Caruso D, Maggi A 2018 Short-term fasting reveals AA metabolism as a major sex discriminating factor in the liver. Cell Metabolism [epub]. (https://doi.org/10.1016/j.cmet.2018.05.021)

Dupont S, Krust A, Gansmuller A, Dierich A, Chambon P \& Mark M 2000 Effect of single and compound knockouts of estrogen receptors alpha (ERalpha) and beta (ERbeta) on mouse reproductive phenotypes. Development 127 4277-4291.

Fisher CR, Graves KH, Parlow AF \& Simpson ER 1998 Characterization of mice deficient in aromatase (ArKO) because of targeted disruption of the cyp19 gene. PNAS 95 6965-6970. (https://doi.org/10.1073/ pnas.95.12.6965)

Foryst-Ludwig A, Clemenz M, Hohmann S, Hartge M, Sprang C, Frost N, Krikov M, Bhanot S, Barros R, Morani A, et al. 2008 Metabolic actions of estrogen receptor beta (ERbeta) are mediated by a negative cross-talk with PPARgamma. PLoS Genetics 4 e1000108. (https://doi. org/10.1371/journal.pgen.1000108)

Greco TL, Furlow JD, Duello TM \& Gorski J 1991 Immunodetection of estrogen receptors in fetal and neonatal female mouse reproductive tracts. Endocrinology 129 1326-1332. (https://doi.org/10.1210/endo129-3-1326)

Hammes A, Andreassen TK, Spoelgen R, Raila J, Hubner N, Schulz H, Metzger J, Schweigert FJ, Luppa PB, Nykjaer A, et al. 2005 Role of endocytosis in cellular uptake of sex steroids. Cell 122 751-762. (https://doi.org/10.1016/j.cell.2005.06.032)

Hanley K, Rassner U, Jiang Y, Vansomphone D, Crumrine D, Komuves L, Elias PM, Feingold KR \& Williams ML 1996 Hormonal basis for the gender difference in epidermal barrier formation in the fetal rat. Acceleration by estrogen and delay by testosterone. Journal of Clinical Investigation 97 2576-2584. (https://doi.org/10.1172/JCI118706)

Humpel M, Isaksson P, Schaefer O, Kaufmann U, Ciana P, Maggi A \& Schleuning WD 2005 Tissue specificity of 8-prenylnaringenin: protection from ovariectomy induced bone loss with minimal trophic effects on the uterus. Journal of Steroid Biochemistry and Molecular Biology 97 299-305. (https://doi.org/10.1016/j.jsbmb.2005.05.009)

Inamdar LS, Khodnapur BS, Nindi RS, Dasari S \& Seshagiri PB 2015 Differential expression of estrogen receptor alpha in the embryonic adrenal-kidney-gonadal complex of the oviparous lizard, Calotes versicolor (Daud.). General and Comparative Endocrinology 220 55-60. (https://doi.org/10.1016/j.ygcen.2014.08.003)

Jensen EV 2005 The contribution of 'alternative approaches' to understanding steroid hormone action. Molecular Endocrinology 19 1439-1442. (https://doi.org/10.1210/me.2005-0154)

Jones ME, Thorburn AW, Britt KL, Hewitt KN, Wreford NG, Proietto J, Oz OK, Leury BJ, Robertson KM, Yao S, et al. 2000 Aromatase-deficient (ArKO) mice have a phenotype of increased adiposity. PNAS 97 12735-12740. (https://doi.org/10.1073/pnas.97.23.12735)

Kininis M \& Kraus WL 2008 A global view of transcriptional regulation by nuclear receptors: gene expression, factor localization, and DNA sequence analysis. Nuclear Receptor Signaling 6 e005. (https://doi. org/10.1621/nrs.06005)

Klotz DM, Hewitt SC, Ciana P, Raviscioni M, Lindzey JK, Foley J, Maggi A, DiAugustine RP \& Korach KS 2002 Requirement of estrogen receptor-alpha in insulin-like growth factor-1 (IGF-1)-induced uterine responses and in vivo evidence for IGF-1/estrogen receptor crosstalk. Journal of Biological Chemistry 277 8531-8537. (https://doi. org/10.1074/jbc.M109592200)

Korach KS, Horigome T, Tomooka Y, Yamashita S, Newbold RR \& McLachlan JA 1988 Immunodetection of estrogen receptor in epithelial and stromal tissues of neonatal mouse uterus. PNAS $\mathbf{8 5}$ 3334-3337. (https://doi.org/10.1073/pnas.85.10.3334)

Krege JH, Hodgin JB, Couse JF, Enmark E, Warner M, Mahler JF, Sar M, Korach KS, Gustafsson JA \& Smithies O 1998 Generation and reproductive phenotypes of mice lacking estrogen receptor beta. PNAS 95 15677-15682. (https://doi.org/10.1073/pnas.95.26.15677)

Kudwa AE, Michopoulos V, Gatewood JD \& Rissman EF 2006 Roles of estrogen receptors alpha and beta in differentiation of mouse sexual http://joe.endocrinology-journals.org

https://doi.org/10.1530/JOE-18-0003 (c) 2018 The authors Published by Bioscientifica Ltd. Printed in Great Britain

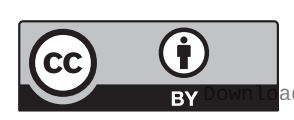

This work is licensed under a Creative Commons Attribution 4.0 Unported License.

ded from Bioscientifica.com at 04/26/2023 10:59:38AM 
behavior. Neuroscience 138 921-928. (https://doi.org/10.1016/j. neuroscience.2005.10.018)

Kummer S, Jeruschke S, Wegerich LV, Peters A, Lehmann P, Seibt A, Mueller F, Koleganova N, Halbenz E, Schmitt CP, et al. 2011 Estrogen receptor alpha expression in podocytes mediates protection against apoptosis in-vitro and in-vivo. PLoS ONE 6 e27457. (https://doi. org/10.1371/journal.pone.0027457)

Lane PH 2008 Estrogen receptors in the kidney: lessons from genetically altered mice. Gender Medicine 5 (Supplement A) S11-S18. (https://doi. org/10.1016/j.genm.2008.03.003)

Lapid K, Lim A, Clegg DJ, Zeve D \& Graff JM 2014 Oestrogen signalling in white adipose progenitor cells inhibits differentiation into brown adipose and smooth muscle cells. Nature Communications 55196. (https://doi.org/10.1038/ncomms6196)

Lemmen JG, Broekhof JL, Kuiper GG, Gustafsson JA, van der Saag PT \& van der Burg B 1999 Expression of estrogen receptor alpha and beta during mouse embryogenesis. Mechanisms of Development 81 163-167. (https://doi.org/10.1016/S0925-4773(98)00223-8)

Lemmen JG, van den Brink CE, Legler J, van der Saag PT \& van der Burg B 2002 Detection of oestrogenic activity of steroids present during mammalian gestation using oestrogen receptor alpha- and oestrogen receptor beta-specific in vitro assays. Journal of Endocrinology $\mathbf{1 7 4}$ 435-446. (https://doi.org/10.1677/joe.0.1740435)

Li Y, Birnbaumer L \& Teng CT 2010 Regulation of ERRalpha gene expression by estrogen receptor agonists and antagonists in SKBR3 breast cancer cells: differential molecular mechanisms mediated by $\mathrm{g}$ protein-coupled receptor GPR30/GPER-1. Molecular Endocrinology 24 969-980. (https://doi.org/10.1210/me.2009-0148)

Lubahn DB, Moyer JS, Golding TS, Couse JF, Korach KS \& Smithies O 1993 Alteration of reproductive function but not prenatal sexual development after insertional disruption of the mouse estrogen receptor gene. PNAS 90 11162-11166. (https://doi.org/10.1073/ pnas.90.23.11162)

Luo J, Sladek R, Bader JA, Matthyssen A, Rossant J \& Giguere V 1997 Placental abnormalities in mouse embryos lacking the orphan nuclear receptor ERR-beta. Nature 388 778-782. (https://doi. org/10.1038/42022)

Maggi A \& Ciana P 2005 Reporter mice and drug discovery and development. Nature Reviews Drug Discovery 4 249-255. (https://doi org/10.1038/nrd1661)

Maggi A, Ciana P, Belcredito S \& Vegeto E 2004 Estrogens in the nervous system: mechanisms and nonreproductive functions. Annual Review of Physiology 66 291-313. (https://doi.org/10.1146/annurev. physiol.66.032802.154945)

Maniu A, Aberdeen GW, Lynch TJ, Nadler JL, Kim SO, Quon MJ, Pepe GJ \& Albrecht ED 2016 Estrogen deprivation in primate pregnancy leads to insulin resistance in offspring. Journal of Endocrinology 230 171-183. (https://doi.org/10.1530/JOE-15-0530)

Markiewicz M, Znoyko S, Stawski L, Ghatnekar A, Gilkeson G \& Trojanowska M 2013 A role for estrogen receptor-alpha and estrogen receptor-beta in collagen biosynthesis in mouse skin. Journal of Investigative Dermatology 133 120-127. (https://doi.org/10.1038/ jid.2012.264)

Mendel CM 1989 The free hormone hypothesis: a physiologically based mathematical model. Endocrine Reviews 10 232-274. (https://doi. org/10.1210/edrv-10-3-232)

Mogi K, Takanashi H, Nagasawa M \& Kikusui T 2015 Sex differences in spatiotemporal expression of AR, ERalpha, and ERbeta mRNA in the perinatal mouse brain. Neuroscience Letters 584 88-92. (https://doi. org/10.1016/j.neulet.2014.10.028)

Munger SC, Natarajan A, Looger LL, Ohler U \& Capel B 2013 Fine time course expression analysis identifies cascades of activation and repression and maps a putative regulator of mammalian sex determination. PLoS Genetics 9 e1003630. (https://doi.org/10.1371/ journal.pgen.1003630)
Mussi P, Liao L, Park SE, Ciana P, Maggi A, Katzenellenbogen BS, Xu J \& O'Malley BW 2006 Haploinsufficiency of the corepressor of estrogen receptor activity (REA) enhances estrogen receptor function in the mammary gland. PNAS 103 16716-16721. (https://doi.org/10.1073/ pnas.0607768103)

Nielsen M, Bjornsdottir S, Hoyer PE \& Byskov AG 2000 Ontogeny of oestrogen receptor alpha in gonads and sex ducts of fetal and newborn mice. Journal of Reproduction and Fertility 118 195-204. (https://doi.org/10.1530/jrf.0.1180195)

Pang SF, Caggiula AR, Gay VL, Goodman RL \& Pang CS 1979 Serum concentrations of testosterone, oestrogens, luteinizing hormone and follicle-stimulating hormone in male and female rats during the critical period of neural sexual differentiation. Journal of Endocrinology 80 103-110. (https://doi.org/10.1677/joe.0.0800103)

Park CJ, Chen G, Koo Y, Lin PP, Cacioppo JA, Prohaska H \& Ko CJ 2017 Generation and characterization of an estrogen receptor alphaiCre knock-in mouse. Genesis 55 1-18. (https://doi.org/10.1002/ dvg.23084)

Partanen AM 1990 Epidermal growth factor and transforming growth factor-alpha in the development of epithelial-mesenchymal organs of the mouse. Current Topics in Developmental Biology 24 31-55.

Patrone C, Cassel TN, Pettersson K, Piao YS, Cheng G, Ciana P, Maggi A, Warner M, Gustafsson JA \& Nord M 2003 Regulation of postnatal lung development and homeostasis by estrogen receptor beta. Molecular and Cellular Biology 23 8542-8552. (https://doi.org/10.1128/ МСB.23.23.8542-8552.2003)

Penza M, Jeremic M, Marrazzo E, Maggi A, Ciana P, Rando G, Grigolato PG \& Di Lorenzo D 2011 The environmental chemical tributyltin chloride (TBT) shows both estrogenic and adipogenic activities in mice which might depend on the exposure dose. Toxicology and Applied Pharmacology 255 65-75. (https://doi. org/10.1016/j.taap.2011.05.017)

Phoenix CH, Goy RW, Gerall AA \& Young WC 1959 Organizing action of prenatally administered testosterone propionate on the tissues mediating mating behavior in the female guinea pig. Endocrinology 65 369-382. (https://doi.org/10.1210/endo-65-3-369)

Revankar CM, Cimino DF, Sklar LA, Arterburn JB \& Prossnitz ER 2005 A transmembrane intracellular estrogen receptor mediates rapid cell signaling. Science 307 1625-1630. (https://doi.org/10.1126/ science.1106943)

Rissman EF, Early AH, Taylor JA, Korach KS \& Lubahn DB 1997 Estrogen receptors are essential for female sexual receptivity. Endocrinology 138 507-510. (https://doi.org/10.1210/endo.138.1.4985)

Rizzi N, Rebecchi M, Levandis G, Ciana P \& Maggi A 2017 Identification of novel loci for the generation of reporter mice. Nucleic Acids Research 45 e37. (https://doi.org/10.1093/nar/gkw1142)

Savu L, Benassayag C, Vallette G, Christeff N \& Nunez E 1981 Mouse alpha 1-fetoprotein and albumin. A comparison of their binding properties with estrogen and fatty acid ligands. Journal of Biological Chemistry 256 9414-9418.

Soto U, Pepperkok R, Ansorge W, Just WW 1993 Import of firefly luciferase into mammalian peroxisomes in vivo requires nucleoside triphosphates. Experimental Cell Research 205 66-75.

Tait S, Tassinari R, Maranghi F \& Mantovani A 2015 Bisphenol A affects placental layers morphology and angiogenesis during early pregnancy phase in mice. Journal of Applied Toxicology 35 1278-1291. (https:// doi.org/10.1002/jat.3176)

Takeyama J, Suzuki T, Inoue S, Kaneko C, Nagura H, Harada N \& Sasano H 2001 Expression and cellular localization of estrogen receptors alpha and beta in the human fetus. Journal of Clinical Endocrinology and Metabolism 86 2258-2262. (https://doi. org/10.1210/jcem.86.5.7447)

Thornton JW, Need E \& Crews D 2003 Resurrecting the ancestral steroid receptor: ancient origin of estrogen signaling. Science 301 1714-1717. (https://doi.org/10.1126/science.1086185) http://joe.endocrinology-journals.org

https://doi.org/10.1530/JOE-18-0003 (c) 2018 The authors Published by Bioscientifica Ltd. Printed in Great Britain

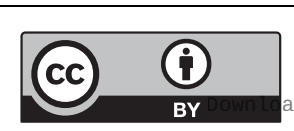

This work is licensed under a Creative Common Attribution 4.0 Unported License.

Aed from Bioscientifica com at 04/26/2023 10:59:38AM 
Thuresson-Klein A, Moawad AH \& Hedqvist P 1985 Estrogen stimulates formation of lamellar bodies and release of surfactant in the rat fetal lung. American Journal of Obstetrics and Gynecology 151 506-514. (https://doi.org/10.1016/0002-9378(85)90279-0)

Tobet SA, Zahniser DJ \& Baum MJ 1986 Sexual dimorphism in the preoptic/anterior hypothalamic area of ferrets: effects of adult exposure to sex steroids. Brain Research 364 249-257. (https://doi. org/10.1016/0006-8993(86)90837-1)

Toft D \& Gorski J 1966 A receptor molecule for estrogens: isolation from the rat uterus and preliminary characterization. PNAS 55 1574-1581. (https://doi.org/10.1073/pnas.55.6.1574)

Tsai MJ \& O'Malley BW 1994 Molecular mechanisms of action of steroid/thyroid receptor superfamily members. Annual Review of Biochemistry 63 451-486. (https://doi.org/10.1146/annurev. bi.63.070194.002315)

Ueberschlag-Pitiot V, Stantzou A, Messeant J, Lemaitre M, Owens DJ, Noirez P, Roy P, Agbulut O, Metzger D \& Ferry A 2017 Gonadrelated factors promote muscle performance gain during postnatal development in male and female mice. American Journal of Physiology: Endocrinology and Metabolism 313 E12-E25. (https://doi.org/10.1152/ ajpendo.00446.2016)
Vantaggiato C, Dell'Omo G, Ramachandran B, Manni I, Radaelli E, Scanziani E, Piaggio G, Maggi A \& Ciana P 2016 Bioluminescence imaging of estrogen receptor activity during breast cancer progression. American Journal of Nuclear Medicine and Molecular Imaging $632-41$.

Walker VR \& Korach KS 2004 Estrogen receptor knockout mice as a model for endocrine research. ILAR Journal 45 455-461. (https://doi. org/10.1093/ilar.45.4.455)

Walker KA, Caruana G, Bertram JF \& McInnes KJ 2009 Sexual dimorphism in mouse metanephroi exposed to 17 beta-estradiol in vitro. Nephron Experimental Nephrology 111 e42-e50. (https://doi. org/10.1159/000191104)

Yuchi Y, Cai Y, Legein B, De Groef S, Leuckx G, Coppens V, Van Overmeire E, Staels W, De Leu N, Martens G, et al. 2015 Estrogen receptor alpha regulates beta-cell formation during pancreas development and following injury. Diabetes 64 3218-3228. (https:// doi.org/10.2337/db14-1798)

Zoller AL \& Kersh GJ 2006 Estrogen induces thymic atrophy by eliminating early thymic progenitors and inhibiting proliferation of beta-selected thymocytes. Journal of Immunology 176 7371-7378. (https://doi.org/10.4049/jimmunol.176.12.7371)

Received in final form 5 June 2018

Accepted 11 June 2018
This work is licensed under a Creative Commons Attribution 4.0 Unported License. 